\title{
MAMMALIAN HYBRIDS
}

\section{A CHECK-LIST WITH BIBLIOGRAPHY}

\author{
by Annie P. Gray
}

This compilation, which has become a classic reference book, has been out of print for some time. The new edition, published in 1972, contains nearly twice as many entries and a bibliography of well over 1200 titles.

Cloth boards $x+262$ pages Price $\mathrm{f} 4.00(\$ 10.40) \quad$ SBN 851981704

Order through any bookseller or from the publishers

Central Sales

Commonwealth Agricultural Bureaux

Farnham Royal, SLOUGH SL2 3BN, Bucks., England

\section{The Journal of General Microbiology}

\section{Partial Contents of Volume 74, Part 2, February 1973}

DEVELOPMENT AND STRUCTURE

A. M. P. DooijewaArd-Kloosterziel, J. H. Sietsma and J. T. M. Wouters Formation and Regeneration of Geotrichum candidum Protoplasts

J. H. Sietsma and W. R. DE Boer Formation and Regeneration of Protoplasts from Pythium PRL2142

J. F. Peberdy and C. E. BuckLeY Adsorption of Fluorescent Brighteners by Regenerating Protoplasts of Aspergillus nidulans

M. Fletcher and G. D. Floodgate An Electron Microscopic Demonstration of an Acidic Polysaccharide Involved in the Adhesion of a Marine Bacterium to Solid Surfaces

PHYSIOLOGY AND GROWTH

R. F. Gomez, A. J. Sinskey, R. Davies and T. P. Labuza Minimal Medium Recovery of Heated Salmonella typhimurium LT2

B. SEDDON and G. H. FYNN Energetics of Growth in a Tyrothricin-producing Strain of Bacillus brevis BIOCHEMISTRY

I. W. Sutherland and M. L. SMith The Lipopolysaccharides of Fruiting and Non-fruiting Myxobacteria

G. W. Gooday, P. Fawcett, D. Green and G. Shaw The Formation of Fungal Sporopollenin in the Zygospore Wall of Mucor mucedo: a Role for the Sexual Carotenogenesis in the Mucorales

Y. OKon, I. Chet and Y. Henis Effects of Lactose, Ethanol and Cycloheximide on the Translocation Pattern of Radioactive Compounds and on Sclerotium Formation in Schlerotium rolfsii

S. B. Samuels, C. W. Moss and R. E. Weaver The Fatty Acids of Pseudomonas multivorans (Pseudomonas cepacia) and Pseudomonas kingii

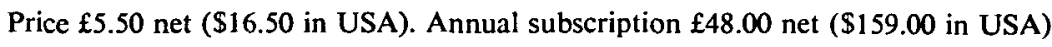

CAMBRIDGE UNIVERSITY PRESS

Bentley House, 200 Euston Road, London NW1 2DB

American Branch: 32 East 57th Street, New York, N.Y. 10022 
Genet. Res., Camb.

\section{GENETICAL \\ RESEARCH}

VOLUME 21, NUMBER 1, FEBRUARY 1973

\section{CONTENTS}

PICARD, MARGUERITE. Genetic evidence for a polycistronic unit of transcription in the complex locus '14' in Podospora anserina

page 1

JAMES, A. P. Meiotic reversion in an unstable strain of yeast

BELL, A. E. and BURRIS, MARTIN J. Simultaneous selection for two correlated traits in Tribolium

matSUмото, нideкI. Genetic recombination between Klebsiella pneumoniae and Enterobacter aerogenes

GRIMES, GARY W. An analysis of the determinative difference between singlets and doublets of Oxytricha fallax

ACHTMAN, MARK. Transfer-positive J-independent revertants of the F factor in Escherichia coli K 12

WHEALS, A. E. Developmental mutants in a homothallic strain of Physarum polycephalum

DEE, JENNIFER, WhEALS, A. E. and HOLT, C. E. Inheritance of plasmodial valine requirement in Physarum polycephalum

SHORT PAPER

HOLLOWAY, B. W. and RICHMOND, M. H. R-Factors used for genetic studies in strains of Pseudomonas aeruginosa and their origin

\section{CAMBRIDGE UNIVERSITY PRESS}

Bentley House, 200 Euston Road, London NW 12 DB

American Branch: 32 East 57th Street, New York, N.Y.10022

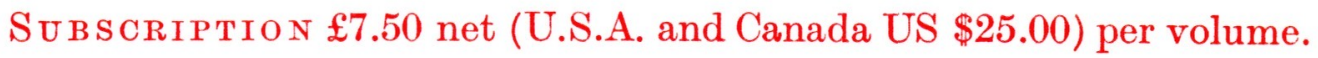
Single Parts $£ 3.00$ net (U.S.A. and Canada US \$9.50) 